\title{
ЗАВХАН АЙМГИЙН ХАДЛАН БЭЛЧЭЭРИЙН АСУУДАЛД
}

\section{Н.Нарантуяа}

ШУА-ийн Ерөнхий болон сорильн биологийн хүрээлэн, Монгол улс Цахим шуудан: narntuya@gmail.com

\section{ХУРААНГУЙ}

ЭнэхүУ өгүүлэлд монгол орны хадлан бэлчээрийн сүҮлийн 30 гаруй жилийн судалгааны болон Завхан аймагт 2014-2017 онуудад хийгдсэн судалгааны үр дүнг нэгтгэн боловсруулав. Завхан аймгийн хадлан бэлчээрийн үнэлгээний дүнгээ харахад Завхан аймгийн хадлан бэлчээрийн нийт талбай 7850.3 мянган га, 55975.15 мянган иеентр ургаџын нөөцтэй, ургамал бүлгэмдэл 6.5-7.7 и/га ургаитай байна.

Завхан аймгийн хадлан бэлчээр нь биологи-экологийн чанарын үнэлгээгээр IY, Y, YI бүлэгт хамрагдаж байна. Зуны дээд ургаиаар бодоход тэжээлийн өндөр ургаитай чанарын I бүлэгт голын сав, нуурын хөвөөний, нуга, нуга-намгийн бэлчээрийн эдэлбэр хамрагдах бөгөөд харьиангуй өндөр ургаџтай чанарын III бүлэгт татмын нуга, нуга-намгийн тэжэээлйн эдэлбэр орно.

Түлхүур үгс: Хадлан бэлчээр, ургаи, бэлчээрийн дааи, багтаамж, хадлан бэлчээрийн биологи-экологийн чанарын үнэлгээ;

\section{ОРШИЛ}

Завхан аймаг нь Монгол улсын баруун хойд хэсэгт дорнод уртрагийн $93^{0} 16^{\prime}$-аaс $99^{0} 12^{\prime}$, хойд өргөргийн $46^{0} 33^{\prime}$-аaс $50^{0} 23^{\prime}$ хооронд оршдог. Хойноос урд хүртэл 610 км, баруунаас зүҮн хүртэл 520 км, 82.5 мянган км2 нутаг дэвсгэртэй бөгөөд Хангайн нурууны өндөрлөгийн баруун хэсэг, Их нууруудын хотгорын зүүн, Монгол Алтайн нурууны салбар уулсын хойд хэсэгт оршдог. Монгол орны хүйтэн бүс нутагт хамрагддаг, хамгийн хүйтэн цэг нь $-53 \mathrm{C}^{0}$ хүрч хүйтэрдэг Тосонцэнгэл сум бөгөөд 1-p сарын дундаж температур -20- -30 хэм, өндөр уулсаар жилд 400 мм, баруун хэсгээрээ 80-100 мм, бусад нутгаар 200-206 мм хур тунадас унадаг бүс нутаг (2) юм.

Завхан аймгийн нутаг дэвсгэрийн хүрээнд ургамалжлын босоо чиглэлд өндөр уулын ян оргил, сарьдаг, тагийн тундр, тагийн нуга, ияарам гэсэн 5 дэд бүс, ойн бүслүүр нь цармынн ой, тайга, тайгажуу ой, тайгархаг ой гэсэн 4 дэд бүслүүр (1), хээрийн бүслүүр нь өндөр уульин хээр, уульын хээр, нугын хээр, уульын цөлөрхөг хээр гэсэн 4 дэд бүслүүр үүсгэх ба өргөргийн дагуу хэвтээ чиглэлд хээрийн бүсэд хамаарах хуурай хээр, цөлөрхөг хээр, 
цөлийн хээрийн гэсэн 3 дэд бүстэй. Харин нууруудын хотгорын хужир мараат газраар цөлийн элементүүд орж ирсэн байдаг. Ургамалжлын энэ онцлог нь монгол орны байгалийн үндсэн бүс бүслүүрийн 5 бүс, бүслүүрийн ургамалжлыг хамарсан их өвөрмөц юм.

Бид ШУА, Завхан аймгийн Засаг даргын ТГ-ын хоорондын хамтын ажиллагааны

\section{СУДАЛГААНЫ ОБЬЕКТ, АРГАЗУЙ}

Судалгаанд Завхан аймгийн 21 сумын нутаг дэвсгэрт тархах хадлан бэлчээрийн үндсэн хэвшинжүүдийг хамруулав. Орос Монголын хамтарсан Биологийн иж бүрэн экспедицийн (3) болон ХААИС-ийн МААЭШХ-гээс манай орны хээр, цөл, ойт хээр, нугын 50 гаруй хэвшинжийн ургац тодорхойлсон 20 гаруй жилийн судалгааны материал, аргазүйг ашиглав (6).

Хадлан бэлчээрийн биолого-экологийн үнэлгээг өгөхдөө нарын (1981) Дундад Азийн цөлийн бэлчээрт чанарын зэрэглэл (5) тогтоосон баримтлалыг үндэслэн нийт ургац, хүрээнд Завхан аймгийн экосистемийн судалгааг 2014-2016 онуудад хийж гүйцэтгэсэн ба өөрсдийн судалгааны дүнг, өмнөх олон жилийн судалгааны үр дүнтэй дүйцүүлэн, нэгтгэн боловсруулав.

“Монгол орны хадлан бэлчээр" 2009 онд хэвлэгдсэн М:1:1000.000 хэмжээст зургийн хүрээнд хийгдсэн төслийн судалгааны үр дүнд (6) суурилав.

түүнээс малд идэгдэх ургац болон нэг га-д агуулагдах тэжээлийн нэгжийн хэмжээг голлох хэмнүүр болгон авч, бэлчээрийн ус чийгийн хангамж, хотгор, гүдгэрийн байдал зэргийг харгалзан үзэж, монгол орны хадлан бэлчээрийг чанарын 8 бүлэгт ангилан хуваасан аргазүйг үнэлгээний зарчим болгон ашигласан болно.

Бэлчээрийн даац багтаамжийг тодорхойлохдоо малд идэгдэх ургацын хэмжээнээс гадна бэлчээр ашиглалтын хугацаа, байгалийн бэлчээрээс малын хоногт идэх өвсний хэмжээг хонин толгойд шилжүүлэн тооцов.

\section{СУДАЛГААНЫ ҮР ДҮН}

Монгол орны хадлан бэлчээрийн хэвшинж тус бүрийн талбайг тодорхойлж, ургацыг тогтоож, ургацын шимт чанарын үнэлгээг 1 га- д агуулагдах кг тэжээлийн нэгж, шингэх протейны хэмжээгээр

тодорхойлсон нь байгалийн хадлан бэлчээрт биологи, экологийн үнэлгээ өгөхөд голлох хэмнүүр (6) болов (Хүснэгт 1).

ХУснэгт 1. Бэлчээрийн 1кг өвс ногооны иимт чанар

\begin{tabular}{|c|c|c|c|c|c|}
\hline \multirow{2}{*}{} & \multirow{2}{*}{ Байгалийн бүс бүслүүр } & \multicolumn{2}{|c|}{ Зун намар } & \multicolumn{2}{|c|}{ Өвөл хавар } \\
\cline { 3 - 6 } & & $\begin{array}{c}\text { Тэжээлийн } \\
\text { нэгж кг }\end{array}$ & $\begin{array}{c}\text { Шингэх } \\
\text { протейн кг }\end{array}$ & $\begin{array}{c}\text { Тэжээлийн } \\
\text { нэгж кг }\end{array}$ & $\begin{array}{c}\text { Шингэх } \\
\text { протейн кг }\end{array}$ \\
\hline 1 & Өндөр уулын бүслүүр & 0.60 & 0.062 & 0.26 & 0.016 \\
\hline 2 & Ойт хээрийн бүслүүр & 0.63 & 0.053 & 0.32 & 0.016 \\
\hline 3 & Хээрийн бүс & 0.57 & 0.054 & $0 / 27$ & 0.026 \\
\hline 4 & Цөлийн ба цөлөрхөг хээр & $0 / 68$ & $0 / 077$ & 0.44 & 0.033 \\
\hline 5 & Татмын ба эх газрын нуга & 0.56 & 0.074 & 0.25 & 0.022 \\
\hline
\end{tabular}

Байгалийн хадлан бэлчээрийн ургац, судалгааны дээрх материал болон ХААИСтүҮний хөдлөлзүйг судалсан олон жилийн ийн МААЭШХ-гээс боловсруулсан гарын $-76-$ 
авлагыг үндэслэн хадлан бэлчээрийн бүслүүрээр тоймлон гаргав. (хүснэгт2) ургацын хагдарч, хадгалагдах байдлыг бүс

Хүснэгт 2. Байгалийн хадлан бэлчээрийн хагдарч хадгалагдах байдал

\begin{tabular}{|c|l|c|c|}
\hline \multirow{2}{*}{$№$} & \multirow{2}{*}{ Хадлан бэлчээрийн анги, дэд анги } & \multicolumn{2}{|c|}{ Зуны дээд ургацын хадгалалтын байдал \% } \\
\cline { 3 - 4 } & & Зун-намар & Өвөл-хавар \\
\hline 1 & Өндөр уулын & 80 & 60 \\
\hline 2 & Уулын ой, ойт хээрийн & 80 & 60 \\
\hline 3 & Уулын нугажуу хээрийн & 80 & 60 \\
\hline 4 & Уулын хээрийн & 80 & 60 \\
\hline 5 & Хуурай хээрийн & 65 & 40 \\
\hline 6 & Цөлжүү хээрийн & 60 & 40 \\
\hline 7 & Цөлийн хээрийн & 60 & 40 \\
\hline 8 & Цөлийн & 60 & 60 \\
\hline 9 & Давсархаг хотгорын & 80 & 50 \\
\hline 10 & Татмын нуга, нуга, намгийн & 70 & 40 \\
\hline
\end{tabular}

Хадлан бэлчээрийн ургацын өвөл, хавар, зун, намрын улиралд хадгалагдах байдлыг тогтоосон нь бэлчээрийн даац багтаамжийг тодорхойлоход чухал үүрэгтэй юм.

Нэг га талбайд бэлчээрлүүлэх сүргийн тоо хэмжээг хоног, сар, улирлаар илэрхийлсэн үзүүлэлт бол бэлчээрийн хэвийн ачаалал буюу багтаамж, даац юм.

Хэрэв бэлчээрийг ашиглах хугацаанд нэгж талбайд ноогдох малын тоо зохих тоо хэмжээнээс бага байвал тухайн бэлчээрийн өвс бүрэн ашиглагдаж чаддаггүй өөрөөр хэлбэл ургамлын ихэнхийг мал идэхгүй үлдээж, улмаар ургамал хөгширч борогшин шингэц шимт чанар нь буурна, харин бэлчээрийн ачааллыг хэтрүүлбэл ургамлын ургац буурч, бэлчээр талхлах гол нөхцөл бүрддэг. Иймд бэлчээрийн ачааллыг зөв тогтоохын тулд: а. бэлчээрээс малын өдөрт идэх өвсний хэмжээ, б. малд идэгдэх ургац (бодит ургац), в. Бэлчээр ашиглалтын хугацааг зайлшгүй мэдэх шаардлагатай (Лхагважав, 1979). Бэлчээрээс малын хоногт идэх өвсний хэмжээг нэг хонин толгойд шилжүүлэн, нутгийн нэг хонины өдөрт идэх өвсний хэмжээг МААЭШХ-с гаргасан гарын авлагыг үндэслэн байгалийн бүс бүслүүрээр тооцон гаргав (6) (хүснэгт 3).

Хүснэгт 3. Бэлчээрээс нутгийн Үүлдрийн нэг хонин толгойн өдөрт идэх өвсний хэмжсээ

\begin{tabular}{|c|c|c|}
\hline Байгалийн бүс бүслүүр & Улирал & Өвс, ногоо ( кг) \\
\hline \multirow{2}{*}{ Өндөр уулын бүслүүр } & Зун-намар & 1.6 \\
& Өвөл-хавар & 1.5 \\
\hline \multirow{2}{*}{ Ойт хээрийн бүслүүр } & Зун-намар & 1.8 \\
& Өвөл-хавар & 1.5 \\
\hline \multirow{2}{*}{ Хээрийн бүс } & Зун-намар & 1.8 \\
& Өвөл-хавар & 1.6 \\
\hline \multirow{2}{*}{ Цөлийн ба цөлөрхөг хээрийн бүс } & Зун-намар & 1.5 \\
& Өвөл-хавар & 1.1 \\
\hline \multirow{2}{*}{ Дундаж } & Зун-намар & 1.7 \\
& Өвөл-хавар & 1.4 \\
\hline
\end{tabular}


Малд идэгдэх бодит ургацыг тодорхойлохдоо бэлчээрийн хэвшинжийн нийт ургацыг бэлчээр ашиглалтын коэффициентоор үржүүлж тогтоов.

Ингэж монгол орны хадлан бэлчээрийн ургац, шимт чанар, бэлчээрийн ургамлын хагдарч, хадгалагдах байдал зэрэг үндсэн үзүүлэлтүүдийг тогтоосон аргазүйг ашиглан бид Завхан аймгийн хадлан бэлчээрийн дээрх Үзүүлэлтүудйг тодорхойлж, биологи-экологийн чанарын зэрэглэл"-ээр дүйцүүлэн ангилав (5). Үүнд:

Чанарын I бүлэг. Энэхүү бүлэгт өндөр буюу дунджаар 20ц/га- гаaс дээш ургац бүхий, нэг га талбайд 1000 кг-аас дээш тэжээлийн нэгжтэй тэнцэх шимт чанарын агууламжтай, хотгор, гүдгэрийн болон усан хангамжийн тохиромжтой нөхцөлд оршдог бэсрэг нам уулс, уулсын хаяа бэлийн баялаг алаг өвс-үетэнт, алаг өвст нугажуу хээрийн болон голын сав нуурын хөвөөний нуга, намгийн бэлчээр тус тус орно.

Чанарын II бүлэг Харьцангуй өндөр буюу дунджаар 14-20 ц/га ургац бүхий 8011000 кг тэжээлийн нэгжтэй тэнцэх шимт чанарын агууламжтай, усан хангамжийн нөхцлөөр тохиромжтой боловч хотгор, гүдгэрийн хувьд төдийлэн тааламжтай бус орчинд оршдог өндөр уулын хээржүҮ нугын, уулс хоорондох хөндий, бэсрэг нам уулын нугын хээрийн, голын сав, нуурын хөвөөний, татмын нуга, нуга-намгийн бэлчээр энэхүу бүлэгт хамаарна.

Чанарын III бүлэг -т $10.5-14.0$ ц/га ургац бүхий 601-800 кг тэжээлийн нэгжтэй тэнцэх шимт чанарын агууламжтай, усан хангамжийн нөхцлөөр дунд, зарим газраа харьцангуй сайн боловч ихэнх нь хотгор гүдгэрийн хувьд дунд зэргийн нөхцөлд оршдог уулын хээрийн, уулын хаяа, цав толгодын, уулс хоорондох хөндий, уулын хаяа, бэлийн өндөр өргөгдсөн тэгш тал газрын, нугын хээрийн, голын сав нуурын хөвөөний мод сөөгт бэлчээр тус тус орно.

Чанарын $1 Y$ бүлэг ЭнэхүҮ бүлэгт дунд зэргийн юмуу дунджаар 8-11.0ц/гаургацтай, 1 га-д 401-600 кг тэжээлийн нэгжтэй тэнцэх шимт- чанарын агууламжтай, хотгор, гүдгэрийн харьцангуй тааламжтай нөхцөлд тархдаг боловч ихэнх нь усан хангамжийн нөхцлөөр муу бэлчээр орно. Ийм бэлчээрт бэсрэг нам уулс, уулс, хоорондох хөндий, хаяа, бэлийн нугын хээр, дэгнүүлт юмуу үндэслэг ишт үетэнт эсвэл цав толгодын, ухаа гүвээт тал газрын хуурай хээр, голын хөндийн давссаг үетэнт- заримдаг сөөгт хотгорын бэлчээр орно.

Чанарын $Y$ бүлэг -т харьцангуй бага юмуу дунджаар 5.0-7.9 ц/га ургац бүхий, 1 га-д 251-400 кг тэжээлийн нэгжтэй тэнцэх шимт чанарын агууламжтай бэсрэг нам уулын ойн, давссаг хотгор, хужир мараа бүхий нугын, бэсрэг нам уулын нугын хээр, цав толгодын, ухаа гүвээт тал газрын хуурай хээр, дунд зэрэг ширэгжсэн 300 довцог; манхан элсний бэлчээр хамаарна.

Чанарын Y1 бүлэг-т бага юмуу дунджаар 3.0-5.0 ц/га ургацтай, 1 га-д 101-250 кг тэжээлийн нэгжтэй тэнцэх шимт чанарын агууламжтай, бэсрэг нам уулын тармаг ойт модны, хүйтсэг нугын, бэсрэг уулын дунд зэрэг ширэгжсэн зоо довцог, манхан элсний, цав толгодын, уулын хаяа бэлийн налуу тал газрын заримдаг сөөгөнцөр-дэгнүүлт үетэнт цөлийн хээрийн, цөлжүҮ хээрийн, хээржүү цөлийн хотгор гүдгэрийн хувьд харьцангуй тааламжтай, усан хангамжийн тааламжтай бус нөхцөлд оршдог бэлчээр хамаарна.

Чанарын ҮП бүлэг-т маш бага юмуу дунджаар 1.0-3.0 ц/га ургацтай, 1 га-д 51100 кг тэжээлийн нэгжтэй тэнцэх шимт чанарын агууламжтай, ихэнх хэсэг нь усан хангамжийн тааламжгүй, хотгор гүдгэрийн хувьд янз бүрийн нөхцөлд орших өндөр уулын хаг-хөвдөт, сөөг, сөөгөнцөрт тундрын, уулын хаяа бэлийн налуу тал газрын, хотгорын, цав толгодын, нүцгэн манхан элсний бэлчээр хамаарна.

Чанарын ҮШ бүлэг-т хэт бага буюу дунджаар 0.9 ц/га ургацтай, 0-50 кг тэжээлийн нэгжтэй тэнцэх шимт чанарын агууламжтай, усан хангамжийн маш муу нөхцөлд оршдог хэт хуурай цөлийн, өндөр уулын хаг-хөвдөт тундрын бэлчээр орно. 


\begin{tabular}{|c|c|c|c|c|c|c|c|c|}
\hline 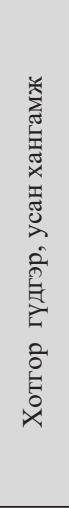 & 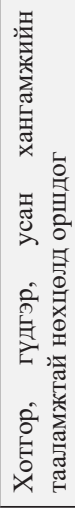 & 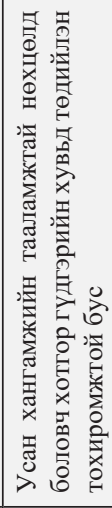 & 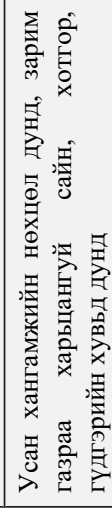 & 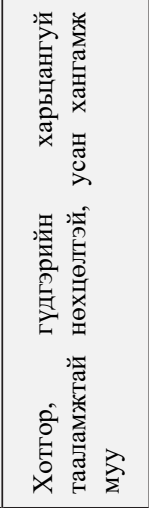 & 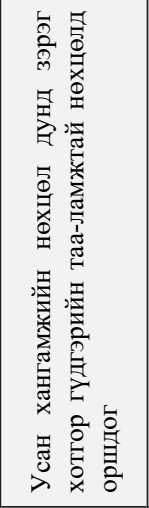 & 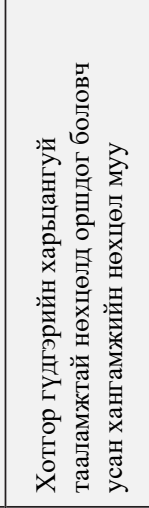 & 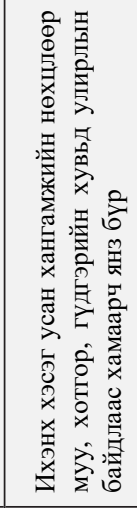 & 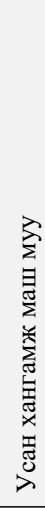 \\
\hline 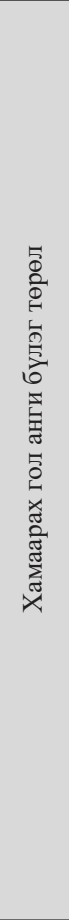 & 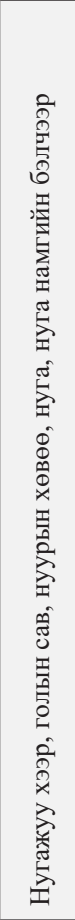 & 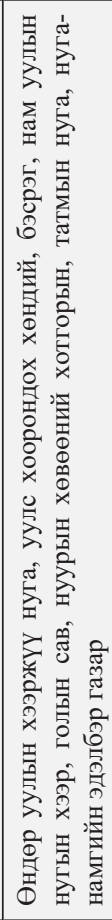 & 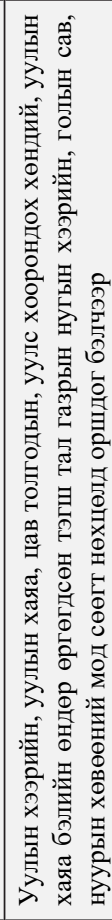 & 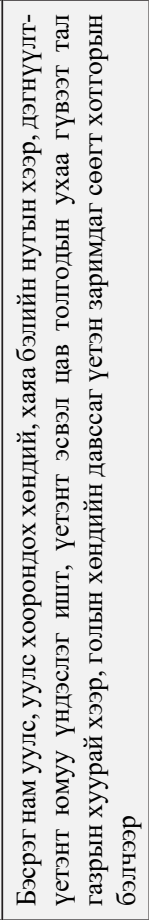 & 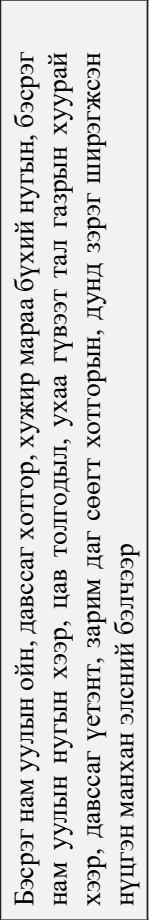 & 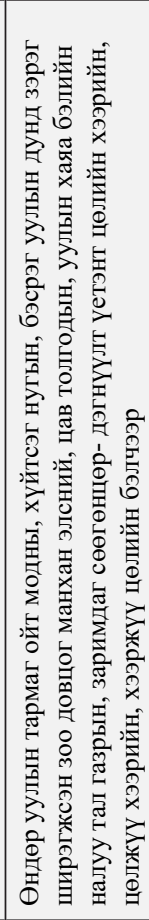 & 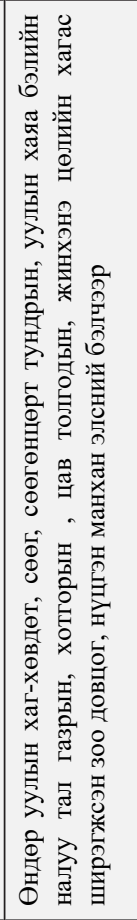 & 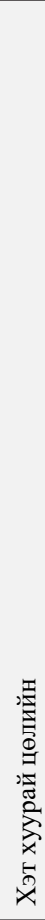 \\
\hline 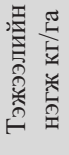 & 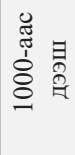 & $\frac{8}{\frac{8}{1}}$ & $\begin{array}{l}8 \\
0 \\
1 \\
1 \\
0\end{array}$ & $\begin{array}{l}8 \\
0 \\
1 \\
\\
\\
+\end{array}$ & $\frac{\stackrel{8}{+}}{\frac{1}{2}}$ & $\begin{array}{l}\stackrel{0}{7} \\
\stackrel{1}{0} \\
0\end{array}$ & $\frac{8}{\frac{8}{n}}$ & in \\
\hline 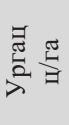 & 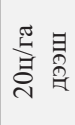 & $\stackrel{\text { Iิ }}{ \pm}$ & $\begin{array}{l}\stackrel{0}{ \pm} \\
\stackrel{1}{\hat{n}} \\
\stackrel{0}{0}\end{array}$ & $\begin{array}{l}0 \\
\\
\vdots \\
\infty \\
\infty\end{array}$ & $\begin{array}{c}a \\
\grave{1} \\
\dot{1}\end{array}$ & $\begin{array}{l}0 \\
\dot{d} \\
0 \\
\dot{n} \\
\dot{n}\end{array}$ & $\begin{array}{l}\stackrel{0}{\hat{j}} \\
\text { d. }\end{array}$ & $\begin{array}{l}\text { oे } \\
\text { iे }\end{array}$ \\
\hline 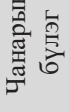 & - & $\exists$ & $\Xi$ & $\beth$ & $\lambda$ & $\bar{\gamma}$ & 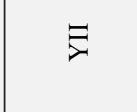 & $\underset{\nearrow}{\exists}$ \\
\hline$\stackrel{201}{5}$ & - & $\sim$ & $m$ & $\nabla$ & in & 0 & $r$ & $\dot{\infty}$ \\
\hline
\end{tabular}


Хадлан бэлчээрийн талбайг талхлагдалд оруулахад мал хэт бэлчээрлүүлэхээс гадна бас жил бүр ямар ч ээлж сэлгээгүйгээр хадлан хадах, зарим эдэлбэр нутгаас бут, сөөгийг түлшинд их хэмжээтэй бэлтгэх зэрэг хүний хүчин зүйлсийн сөрөг Үзэгдлүүд ихээхэн нөлөө үзүүлдэг.

Байгалийн ургамлан нөмрөгийг талхлахгүй байх гол нөхцөл нь хадлан бэлчээриййн даац, багтаамжийг хэтрүүлэхгүй болон тэжээлийн зонхилогч ургамлуудын өсөлт хөгжилтөнд эсрэг нөлөө үзүүлэхгүйгээр зөв зохистой сэлгэн ашиглах явдал юм. Иймээс бэлчээрийн даацыг тодорхойлон тогтоох нь чухал ач холбогдолтой юм. Дээрх монгол орны хадлан бэлчээрийн үнэлгээг хийсэн аргазүй, судалгагааны үр дүнд тулгуурлан Завхан аймгийн хадлан бэлчээрийн хэвшинж тус бүрийг тодорхойлон дүгнэвэл:

\section{1.Завхан аймгийн хадлан бэлчээрийн ерөнхий шинж}

1.1. Өндөр уулын тэжээлийн эдэлбэр.

Өндөр уулын бэлчээр бүгд 650.6 мянган га талбайд тархаж, аймгийн нийт тэжээлийн эдэлбэрийн $\quad 8.2 \%$-ийг эзэлдэг, 2204.7 мянган цн ургацтай бөгөөд аймгийн нийт ургацын 3.9\%-ийг эзэлнэ. Нэг га-д 81.7188.6 кг тэжээлийн нэгжтэй тэнцэх шимт чанарын агууламжтай, биологи-экологийн үнэлгээгээр бага ургацтай юмуу чанарын VI, VII бүлгийн бэлчээрт орно.

\section{2. Уулын ойт хээрийн бэлчээр}

Ургамлан бүлгэмдлийнхээ бүтэц, бүрэлдэхүүн, гадаргын хотгор гүдгэрийн байдлаар хязгаарлагдмал ашиглалт бүхий уулын ойн бүлэг төрөлд хамаарна. Тэнд өвслөг ургамлан бүрхэвчинд Алтайн ботууль, Сибирийн ботууль, зарим зүйлийн бушилз, улалж, Сибирийн биелэг өвс, мухар сорвоо зэрэг ургамал зонхилно.

Уулын ойн бэлчээр 776.2 мянган га талбайд 6198.99 мянган цн ургацтай тархаж, аймгийн нийт тэжээлийн эдэлбэрийн 9.6\%, ургацын 11.1\% эзлэх бөгөөд 234-461 кг/га тэжээлийн нэгжтэй тэнцэх шимт чанарын агууламжтай тул бэлчээрийн чанарын IV, V, VI бүлгийн бэлчээрт орно.

\section{3. Хээрийн тэжээлийн эдэлбэр}

Хээрийн тэжээлийн эдэлбэр бүгд 5719.72 мянган га талбайд 40561 мянган цн ургацтай тархаж аймгийн нийт тэжээлийн эдэлбэрийн $72.8 \%$, ургацын $72.4 \%$ эзэлнэ. Ургамлан нөмрөгийн бүтэц, бүрэлдэхүүн, гадаргын байдлаар дараах 5 бүлэг-төрөлд ангилагдана.
1.3.1. Уулын нугажуу хээрийн тэжээлийн эдэлбэр.

Уулын энгэр хажуугаар хар шороон хэлбэрийн болон хар хүрэн хөрсөнд зонхилон тархана. Чийг, дулаан, гадаргын харьцангуй тохиромжтой нөхцөлд оршдог тул зун-намрын улиралд үхэр, адуу, бог малын бэлчээрт ашиглахад илүY бололцоотой. Нугажуу хээрийн тэжээлийн эдэлбэр бүгд мянган га талбайд, 21406.2 мянган цн ургацтай тархаж, аймгийн нийт хээрийн тэжээлийн эдэлбэрийн $37.1 \%$, ургацын 52.7\%-ийг эзэлнэ.

Ургамлан нөмрөгт нь Цөлийн ба Шеллийн бутнуур, зогдор улалж зонхилж, эмийн сөд, Валисякийн ботууль, соргүй согоовор, хэрчлээст бивлэнцэр, содон хошоонгор зэрэг үетэн, алаг өвс ургана. Уулын нугажуу хээрийн бэлчээр зүйлийн бүрэлдэхүүнээрээ харьцангуй өндөр, 9.310.8ц/га ургацтай, нэг га-д 296-586 кг/га тэжээлийн нэгжтэй тэнцэх шимт чанарын агууламжтай тул чанарын VI бүлгийн бэлчээрт хамрагдана.

1.3.2. Уулын хээрийн тэжээлийн эдэлбэр

Энэхүу ангид уулын энгэр, хаяаны нимгэн хүрэн, хар хүрэн хөрсөнд тархах чулуусаг алаг өвс бүхий ботуульт, жижиг дэгнүүлт үетэнт бэлчээр орно. Усан хангамж, гадаргын хотгор гүдгэр, чийг дулааны байдал болон ургац, түүний шимт чанарын байдлаараа харьцангуй тохиромжтой нөхцөлд оршдог. Бүгд 1123.6 мянган га талбайд 7035.8 мянган 
цн ургацтай тархаж, хээрийн тэжээлийн эдэлбэрийн 19.6\%, ургацын 17.3\% эзэлнэ.

Ургамлан нөмрөгт нь Ленийн болон Валиссийн ботууль, туужууны биелэг өвс, дааган сүүл зэрэг хагдарч хадгалагдахдаа сайн, тэжээлийн шимт чанараар өндөр дэгнүүлт үетэн зонхилно. Мөн агь, үмхий буржгар, цөлийн бутнуур, буурал гандбадраа, содон хошоонгор зэрэг ургамал элбэг ургана.

Уулын хээрийн тэжээлийн эдэлбэрт хамаарах бэлчээр дунджаар 5.7- 6.7 ц/ га ургацтай, 148-312.6 кг/га тэжээлийн нэгж бүхий шимт чанарын агууламжтай бөгөөд бэлчээрийн чанарын $\mathrm{V}$ бүлэгт хамаарна. Дунд зэргийн ургацтай чанарын $\mathrm{V}$ бүлэгт хамаарч байгаа нь уулын хээрийн бэлчээрийг даац, багтаамжаас хэтрүүлэн ашиглаж байгаатай холбоотой юм. Иймээс ч чийг, дулаан, хөрсөн бүрхэвчийн харьцангуй тохиромжтой нөхцөлд оршдог хэдий ч уулын нугажуу хээрийн бэлчээрээс бараг 2 дахин бага ургацтай байгаа юм. Энэ нь Д.Банзрагчийн тодорхойлсноор уулын хээрийн ботуульт бэлчээрт гол төлөв өсөлт, хөгжилт нь эрт зогсдог, сэргэн ургах чадавхи муутай хүйтсүү-чулуусаг ургамал зонхилдог онцлогтой холбоотой юм.

Хуурай хээрийн тэжээлийн эдэлбэр.

Бэсрэг нам уул, цав, толгод, уулын хаяа бэл, тэгш тал газраар 1163.120 мянган га талбайд тархдаг, 7689.7 мянган цн ургацтай бөгөөд хээрийн нийт тэжээлийн эдэлбэрийн $20.3 \%$, ургацын $18.9 \%$ эзэлнэ.

Ургамлан немрөгийн

бүтэц бүрэлдэхүүн, гадаргын байдпаар нь энэхүҮ ангид хамаарах бэлчээр нь бэсрэг нам уул, цав толгод, уулын хаяаны болон тэгш тал газрын, сайн ширэгжсэн 300 довцог элсний гэсэн 2 бүлэг төрөлд ангилагдана.

a. Бэсрэг нам уулс, уулын хаяа бэлийн бэлчээрт уулын нимгэн хүрэн хөрсөнд тархсан невскийн хиагт болон чулуусаг алаг өвс-дэгнүүлт үетэнт, агьерхөг-ботуульт, дэгнүүлт үетэн-хялганат, хялганат болон сөөгт төрлүүд хамаарна. Энэхүү бүлэг төрөлд хамаарах бэлчээр бүгд
1075.1 мянган га талбайд тархаж, хуурай хээрийн бэлчээрийн $92.4 \%$ эзэлнэ.

Ургамлан нөмрөгт нь саман ерхөг, Крыловын хялгана, Ленийн ботууль, Невскийн хиаг, хазаар өвс, дааган сүүл зэрэг тэжээлийн шимт чанараар өндөр үетнүүд зонхилох ба үмхий буржгар, хоёр ишт бэриш, хурдан цагаан зэрэг алаг өвс, зарим зүйлийн шарилжууд элбэг ургана. Хэдийгээр тэжээлийн шимт чанараар өндөр ургамлууд зонхилдог ч усан хангамжийн нөхцөл жигд бус тул ургацын хэмжээ харьцангуй бага юм. Тухайлбал, 5.5-6.4 ц/га ургацтай /дунджаар/, 148-312 кг/ га тэжээлийн нэгж бүхий шимт чанарын агууламжтай бөгөөд бэлчээрийн чанарын V бүлэгт хамаарна.

б. Сайн ширэгжсэн 30о, довцог элсний бэлчээрт хааяа элсэн хурдас бүхий хүрэн хөрсөнд тархсан элссэг ургамалт болон сөөгт бүлгэмдэлтэй дэгнүүлт үетэналаг өвст, сөөгт бэлчээр хамаарна.

Энэ төрлийн бэлчээр нь 87.954 мянган га талбайтай 773.9 мянган цн ургацтай бөгөөд хуурай хээрийн тэжээлийн эдэлбэрийн $7.5 \%$, ургацын $10 \%$ эзлэнэ.

Цөлжүү хээрийн тэжээлийн эдэлбэр

Хаяа уулсын доод хэсэг, цав толгод, уулын хаяа бэл, ухаа гүвээт юмуу тэгш тал газар, элсэн тарамцагаар бүгд 523.6 мянган га талбайд тархаж, аймгийн нийт тэжээлийн эдэлбэрийн 9.1\% эзэлнэ. Харин ургацаар төдийлэн өндөр биш тул аймгийн хээрийн тэжээлийн эдэлбэрийн нийт ургацын 5.2\% тай тэнцэхүйц хэмжээний тэжээлийн нөөцтэй юм.

Ургамланнөмрөгийн бүтэцбүрэлдэхүүн, хөрс, гадаргын хотгор гүдгэрийн байдлаар энэ ангид хамаарах бэлчээр 4 бүлэг төрөлд хуваагдана.

a. Бэсрэг нам уулын бэлчээрт нимгэн цайвар хүрэн хөрсөнд тархсан чулуусаг алаг өвс-агь-өрхөгт, чулуусаг алаг өвс бүхий заримдаг сөөгөнцөр-дэгнүүлт үетэнөдлөг хялганат, зарим газраар сөөг бүхий заримдаг сөөгөнцөр-хиаг, сайрын хялганат, Невскийн хиагт төрлүүд хамаарна. Энэ 
бэлчээр нь 147.79 мянган га талбайтай, 591.199 мянган цн ургацтай бөгөөд аймгийн нийт цөлжүу хээрийн тэжээлийн эдэлбэрийн $28.2 \%$, ургацын $27.9 \%$ эзэлнэ. Энэхүү бэлчээр нь 103-216 кг/га тэжээлийн нэгж бүхий шимт чанарын агууламжтай, 3.7-4.3 ц/га ургацтай тул бэлчээрийн чанарын VI бүлэгт хамаарна.

Ургамлан нөмрөгт нь сайрын хялгана. Невскийн хиаг, саман ерхөг, дэрвээн хазаар өвс, Ленийн ботууль зэрэг тэжээлийн шимт чанараар өндөр дэгнүүлт үетнүүд зонхилно.

б. Цав толгодын бэлчээр-т элсэн хурдас бүхий цайвар хүрэн хөрсөнд тархсан чулуусаг алаг өвс-заримдаг сөөгөнцөрөдлөг хялганат, заримдаг сөөгөнцөр юмуу заримдаг сөөгөнцөр-чулуусаг алаг өвсхиагт бүлгэмдэл хамаарах ба нийт 0.413 мянган га талбайтай, 1.71 мянган цн ургацтай бөгөөд цөлжүү хээрийн тэжээлийн эдэлбэрийн $0.1 \%$, ургацын өчүүхэн бага хувийг эзэлнэ. Бэлчээрийн чанарын VI бүлэгт хамаарна.

в. Ухаа гүвээт, тэгш тал газрын бэлчээрт хааяа элсэн хурдас бүхий цайвар хүрэн хөрсөнд тархах элссүү-хуурайсаг алаг өвс бүхий заримдаг сөөгөнцөрдэгнүүлт үетэн-хазаар өвст, агь-дэгнүүлт үетэнт, ботуульт, монгол өвст, таанат төрлүүд хамаарна. Бүгд 375.134 мянган га талбайтай, 1519.3 мянган цн ургацтай, 100-211 кг/га тэжээлийн нэгж бүхий шимт чанарын агууламжтай, ургамлан бүлгэмдэл 3.7-4.4 ц/га ургацтай тул бэлчээрийн чанарын VI бүлэгт орно. Энэхүу бэлчээр нь цөлжүу хээрийн нийт тэжээлийн эдэлбэрийн 71.6\%, ургацын 71.9\% эзэлнэ.

Ургамлан нөмрөгт нь саман ерхөг, сайрын болон крыловын хялгана, хазаар өвс, Валиссийн ботууль зэрэг хагдарч хадгалагдахдаа сайн, тэжээлийн чанараар өндөр үетэн зонхилно. Ухаа гүвээт юмуу тэгш тал газрын цөлжүү хээрийн тэжээлийн эдэлбэр нутгийг, бэлчээрийн өвс ургамлын бүтэц, хагдарч хадгалагдах байдал, усан хангамж хотгор гүдгэрийн нөхцөлтэй нь хамааралтайгаар өвөл- хаврын юмуу зун-намрын улиралд үхрээс бусад бүх мал бэлчээрлүүлэн ашиглахад илүҮ тохиромжтой.

г. Дунд зэрэг ширэгжсэн 300, довцог болон нүцгэн манхан элсний бэлчээрт зарим газраа Бунгийн харгана бүхий дэгнүүлт үетэн-зээргэнэт, заримдаг сөөгөнцөрзэргэнэт, элссэг ургамалт, заримдаг сөөгөнцөр-элсний шарилжит, элссэг алаг өвс-үетэнт, сөөгт төрлүүд орно.

Ургамлан нөмрөгт нь говийн ба сайрын хялгана, улаан харгана, Невскийн хиаг, таана, хөмөл, шувуун хөл зонхилж саман ерхөг, баглуур, сөөгөн лууль зэрэг үетэн, заримдаг сөөгөнцөр элбэг ургана (4). Тэжээлийн шимт чанар сайтай, хагдарч хадгалагдахдаа сайн ургамлууд зонхилдог хэдий ч ургамлан нөмрөг нь сийрэг, тачир ургамалтай, дунджаар ургамлан бүлгэмдэл 2.6-3.1 ц/га ургацтай, нийт 0.284 мянган га бэлчээрийн талбайтай ба 0.809 мянган цн ургацтай байна. Нэг га-д 70.4-149 кг тэжээлийн нэгж бүхий шимт чанарын агууламжтай бөгөөд бэлчээрийн чанарын VI бүлэгт хамаарна.

Цөлийн хээрийн тэжээлийн эдэлбэр.

Нам уулс, тэгш тал болон хотгор газраар бүгд 786.190 мянган га талбайд 2316.2 мянган цн ургацтай тархаж, нийт хээрийн тэжээлийн эдэлбэрийн 13.7\%, ургацын 5.7\% тус тус эзэлнэ. Ургамлан нөмрөгийн бүтэц, бүрэлдэхүүн, хотгор гүдгэрийн байдлаар энэхүу ангид 4 бүлэг төрөл хамаарна.

a. Нам уулын бэлчээр-т нимгэн, сайргархаг чулуутай цөлийн хээрийн цайвар бор хөрсөнд тархсан харгана бүхий заримдаг сөөгөнцөр-дэгнүүлт үетэн-өдлөг хялганат, агь-дэгнүүлт үетэн-хазаар өвст, дэгнүүлт үетэн- таанат, шарилж юмуу алаг өвс-дэгнүүлт үетэнт-хиагт, ерхөгт, өдлөг хялганат төрлүүд орно.

Ургамлан нөмрөгт нь говийн ба сайрын хялгана, улаан харгана, бор шарилж, Невскийн хиаг, таана зонхилж дэрвээн хазаар өвс, саман ерхөг, баглуур, орог тэсэг, сөөгөн лууль зэрэг үетэн, заримдаг сөөгөнцөр элбэг ургана (4). Хэдийгээр 
энд тэжээлийн шимт чанараар болон хагдарч хадгалагдахдаа сайн ургамлууд зонхилон ургадаг ч нилээд сийрэг, тачир ургамалжилттай тул дунджаар 3.2-3.7 ц/ га ургацтай, 139-215 кг/га тэжээлийн нэгж бүхий шимт чанарын агууламжтай бөгөөд бага ургац бүхий бэлчээрийн чанарын IV бүлэгт хамаарна. Энэ бэлчээр нь 61.150 мянган га талбайтай, 210.9 мянган цн ургацтай бөгөөд нийт цөлийн хээрийн тэжээлийн эдэлбэрийн $\quad 7.7 \%, \quad$ ургацын нөөцийн $9.1 \%$ тус тус эзэлнэ.

б. Цав толгодын бэлдчээр-т нимгэн, сайрархаг чулуутай цайвар бор хөрсөнд тархсан дэгнүүлт үетэн, заримдаг сөөгөнцөр бүхий таана-өдпөг хялганат, таана-өдлөг хялгана-хазаар өвст, сөөгт, шарилжит төрлүүд орно.

Ургамлан нөмрөгт нь сайрын хялгана, таана, хазаар өвс зэрэг үетэн зонхилж, саман ерхөг, Крыловын хялгана, зээргэнэ зэрэг ургамлууд элбэг ургана.

Энэхүу бэлчээр 2.972 мянган га талбайтай, 7.727 мянган цн ургацтай бөгөөд нийт цөлийн хээрийн тэжээлийн эдэлбэрийн $3.8 \%$, ургацын нөөцийн $0.3 \%$ эзэлнэ. Ургамлан нөмрөг нь сийрэг, тачир ургамалжилттай, ургамлан бүлгэмдэл 2.42.8 ц/га ургацтай, 105-162 кг/га тэжээлийн нэгж бүхий шимт чанарын агууламжтай тул бэлчээрийн чанарын VI бүлэгт хамаарна.

в. Уулын хаяа, бэл, налуу тал газрын бэлчээр: хотгордуу хэвгийн, тэгш тал газрын доод хэсэг, нуур, давсархаг хотсын эргэн тойрноор янз бүрийн механик бүтэц бүхий цайвар бор хөрсөнд тархсан харганын сийрэг ширэнгэ бүхий заримдаг сөөгөнцөрбор шаваг-өдлөг хялганат, бор шавагт, заримдаг сөөгөнцөр-баглуур-сайрын хялганат төрлүүд орно (4). Ургамлан нөмрөгт нь говийн болон сайрын хялгана, Artemisia xerophytica, Allium pollyrrhysum, Allium mongolicum зэрэг тэжээлийн шимт чанараар өндөр ургамал зонхилно. ЭнэхүY бэлчээр нь 61.042 мянган га талбай,213.647 мянган цн ургацтай бөгөөд нийт цөлийн хээрийн тэжээлийн эдэлбэрийн $7.7 \%$, ургацын 9.2\% эзэлнэ. Ургамлан бүлгэмдэл тачир сийрэг ургамалжилттай, 3.2-3.8 ц/ га ургацтай, 140.217 кг/га тэжээлийн нэгж бүхий шимт чанарын агууламжтай тул бэлчээрийн чанарын бага ургац бүхий VI бүлэгт хамаарна.

г. Х Хагас ширэгжсэн зоо, довцог болон нүцгэн элсэн манхан элсний бэлчээр-Т элссэг элемент бүхий өдлөг хялганахарганат, шарилж-зээргэнэт, бүйлст бүлгэмдэлтэй ээлжилсэн харгана, элссэг ургамал бүхий өдлөг хялгана-шарилжит, хар сульт бүлгэмдэлтэй ээлжилсэн элсний шарилжит, хар сульт, сөөг бүхий өдлөг хялганат төрлүүд орно. Ургамлан нөмрөгт нь говийн ба сайрын хялгана, зээргэнэ. элсний шарилж, хар суль, бор шаваг зэрэг ургамлууд зонхилно. Хагас ширэгжсэн 300 довцог болон нүцгэн манхан элсний бэлчээр бүгд 661.026 мянган га талбайд 1883.9 мянган цн ургацтай тархаж, нийт цөлийн хээрийн тэжээлийн эдэлбэрийн $84 \%$, ургацын нөөцийн $81.3 \%$ эзлэнэ. Ургамлан бүлгэмдэл 2.6- 3.1 ц/га ургацтай, 117-181 кг/га тэжээлийн нэгж бүхий шимт чанарын агууламжтай тул бэлчээрийн чанарын VI бүлэгт орно.

\section{4. Цөлийн тэжээлийн эдэлбэр}

Элсэнцэр, сайргархуу, чулуурхаг, нимгэн хөнгөн шавранцар, давсархаг, цайвар бор хөрсөнд тархах цөлийн тэжээлийн эдэлбэр бүгд 1499.39 мянган га талбайтай, 307.51 мянган цн ургацын нөөцтэй бөгөөд аймгийн нийт тэжээлийн эдэлбэрийн $1.9 \%$, ургацын нөөцийн $0.6 \%$ эзлэнэ. Ургамлан нөмрөгийн бүтэц, бүрэлдэхүүн, хотгор, гүдгэрийн байдлаар энэХүҮ анги хээржүү цөлийн бэлчээр гэсэн дэд ангид хуваагдана.

\subsection{1. Хээржуу цөлийн бэлчээр}

a. Нам уулын бэлчээр-т элсэнцэр, давсархаг, цайвар бор хөрсөнд тархсан заримдаг сөөгөнцөр-хазаар өвст бүлгэмдэл бүхий заримдаг сөөгөнцөр-өдлөг хялганабаглуурт, харгана бүхий заримдаг сөөгөнцөр- дэгнүүлт үетэн-өдлөг хялганат, хиагт, өдлөг хялгана-баглуурт юмуу сөөгөн 
луульт төрлүүд орно.

Ургамлан нөмрөгт нь хазаар өвс, өдлөг хялгана, түгжгэр баглуур, Невскийн хиаг, сөөгөн лууль зэрэг ургамал зонхилж улаан бударгана, төлөгчдүү боролз, бор харгана, улаан харгана, бүйлс зэрэг ургамал элбэг ургана.

Нам уулсын бэлчээр бүгд 1.8 мянган га талбайтай, 4.905 мянган цн ургацтай. Ургамлан бүлгэмдэл 2.5-2.9 ц/га ургацтай, 1099-168.4 кг/га тэжээлийн нэгж бүхий шимт чанарын агууламжтай тул бэлчээрийн чанарын VI бүлэгт орно.

б. Уулын хаяа бэл, налуу тал газрын бэлчээр. Цөлийн цайвар бор хөрсөнд тархсан зээргэнэ-тэсэгт, сэдэргэнэт, бүрэн хэлбэршээгүй хар сульт, үетэн бүхий заримдаг сөөгөнцөр-баглуурт, шарилжит, өдлөг хялгана- зээргэнэт төрлүүд орно.

Ургамлан нөмрөгт нь орог тэсэг, Горчаковын сэдэргэнэ, түгжгэр баглуур, хонин зээргэнэ зэрэг ургамал зонхилж, сайрын хялгана, нохой шээрэн, төлөгчдүY боролз, улаан бударгана, хазаар өвс, таана зэрэг ургамал элбэг ургана. Ургамлан бүлгэмдэл 1.9-2.2 ц/га ургацтай, 81.8-126.5 кг/га тэжээлийн нэгж бүхий шимт чанарын агууламжтай тул бага ургац бүхий чанарын VI бүлэгт хамаарна.

\section{5. Уст болон хагас уст хэлбэршлийн} давсархаг хотгор, татмын нугын тэжээлийн эдэлбэр

Хужир, мараа бүхий давсархаг хотсын захаар, уст хэлбэршлийн давсархаг болон хужир мараат хөрсөнд бүгд 554.315 мянган га талбайд, 6702.959 мянган цн ургацтай тархах бөгөөд аймгийн нийт тэжээлийн эдэлбэрийн 7.1\%, ургацын нөөцийн $11.9 \%$ эзлэнэ.

Хотгор, гүдгэр, чийгийн нөхцөл, өвс ургамлын бүтэц, бүрэлдэхүүний байдлаараа давссаг үетэнт, заримдаг сөөгт, сөөгөнцөрт болон татмын нугын, нуга, намгийн, нуурын хөвөөний мод сөөгт гэсэн 2 бүлэг-төрөлд ангилагдана.

1.5.1. Давссаг үетэнт, заримдаг сөөгт, сөөгөнцөрт бэлчээр.
Хотгорын бэлчээр-т зарим газраар хармаг, шар бударгана бүхий дэрст, түнхэт, давссаг үетэнт, давссаг алаг өвст, хааяа улалжит, цахилдагт, түнх-сорвоот, загт бүхий зэгст, дэрст сийрэг төгөл төрлүүд орно.

Ургамлан нөмрөгт нь дэрс, нарийн түнх, нарийн сорвоо, турьхан цэцэгт зурман сүүлт зонхилж, орос гэц, шар, улаан бударгана зэрэг ургамал элбэг ургана. Энэ бэлчээр бүгд 233.903 мянган га талбайд 1543.759 мянган цн ургацтай тархах бөгөөд нийт уст болон хагас уст хэлбэршлийн бэлчээрийн 42.1\%, ургацын нөөцийн $2.7 \%$ эзлэнэ. Бэлчээрийн чанарын хувьд 6.1-7.1 ц/га ургацтай, 153-336 кг/га тэжээлийн нэгж бүхий шимт чанарын агууламжтай тул чанарын V бүлэгт орно.

1.5.2. Татмын нуга, намгийн болон голын сав нуурын хөвөөний мод сөөгт бэлчээр

a. Голын хөндийн бэлчээр-т голын сав газрын нугын болон нугын хужир, мараалаг хөрсөнд тархсан зарим газраа шинэсэн ойтой сөөгт, чийгсэг улалжит, үетэн-алаг өвст, сийрэг улиасан төгөл бүхий дэрст, түнхт төрлүүд орно. Ургамлан нөмрөгт нь нугын биелэг өвс, ахар сорт арвай, судалгүй болон ширэг улалж, нумраа хунчир, нугын шимтэглэй, шошлойрхог хошоонгор, хааяа дэрс, нарийн түнх, галуун гичгэнэ зэрэг ургамал зонхилно. Мөн шинэс, улиас, харгана модлог ташингад зонхилон ургана.

Энэхүү бэлчээр бүгд 204.913 мянган га талбайд 2704.85 мянган цн ургацтай тархах бөгөөд нийт уст болон хагас уст хэлбэршлийн тэжээлийн эдэлбэрийн $36.9 \%$, ургацын $40.3 \%$ эзлэнэ. Ургамлан бүлгэмдэл 12.2-14.2 ц/га ургацтай, 304-669 кг/га тэжээлийн нэгж бүхий шимт чанарын агууламжтай тул бэлчээрийн чанарын өндөр ургац бүхий III бүлэгт хамаарна.

б. Хотгорын нугын ба нуурын хөвөө,нуга-намгийн бэлчээр-т аллювийн нугын ширэгжсэн хөрсөнд тархах алаг өвс, намагсаг ургамал бүхий дэрст, түнхт, зэгст, давссаг үетэнт, улалжит, үетэн-алаг өвст 
болон алаг өвс-үетэнт төрлүүд орно.

Ургамлан нөмрөгт нь дэрс, нарийн түнх, хулс, алаг улалж, турьхан цэцэгт зурман сүүл, ахар сорт арвай, нугын биелэг, галуун гичгэнэ, ишгүй азаргана зэрэг үетэн, улалж, алаг өвс зонхилдог. Бүтэц, бүрэлдэхүүний хувьд баялаг, өндөр ургацтай юм. Бүгд 115.499 мянган га талбайд 2454.35 мянган цн ургацтай тархах бөгөөд уст болон хагас уст хэлбэршлийн нийт тэжээлийн эдэлбэрийн 20.8\%, ургацын нөөцийн 36.6\% эзлэнэ. Ургамлан бүлгэмдэл 19.5-23ц/га ургацтай, 487.5-1072.5 кг/га тэжээлийн нэгж бүхий шимт чанарын агууламжтай тул бэлчээрийн чанарын өндөр ургац бүхий I бүлэгт хамаарна.

Завхан аймгийн байгалийн хадлан бэлчээрийн нөөц, багтаамж

Завхан аймгийн хадлан бэлчээрийн хэвшинж тус бүрийн талбай, ургац, шимт чанарын үнэлгээг хийснээс харахад Завхан аймаг нийт 7850.366 мянган га бэлчээрийн талбайтай, зуны дээд ургацаар бодоход 55975.15 мянган цн ургацтай, ургамлан бүлгэмдэл 6.5-7.7 ц/га ургацтай, 196.6397 кг/га тэжээлийн нэгжтэй тэнцэх шимт чанарын агууламжтай, чанарын 1 Y, Y, Y1 бүлэгт хамаарах бэлчээрийн хэвшинжүүд зонхилон тархдаг бөгөөд нийт 5660.98 мянган хонин толгой бэлчээх бэлчээрийн багтаамжтайгаас зуны улиралд 704.12; зун-намрын улиралд 2633.92; өвөл-хаврын улиралд 1049.73 мянган хонин толгой тус тус бэлчээх багтаамжтай байна.

\section{ДҮГНЭЛТ}

Завхан аймгийн хадлан бэлчээрийн нийт талбай 7850.3 мянган га бөгөөд үүний хамгийн их 72,8\% буюу 5712.722 мянган га талбайд хээрийн бэлчээр, хамгийн бага талбайг 8,2\% буюу 650.669 мянган га талбайг өндөр уулын ургамалжил эзлэж байна.

Завхан аймгийн хадлан бэлчээр нь биологи-экологийн үнэлгээгээр чанарын IY, Y, YI бүлэгт хамрагдаж байна.

Завхан аймгийн тэжээлийн эдэлбэр
Завхан аймгийн нийт бэлчээрийн $72.9 \%$ буюу 5719.722 мянган га талбайг хээрийн, $9.9 \%$ буюу 776.27 мянган га талбайг уулын ойн, 8.3\% буюу 650.669 мянган га талбайг өндөр уулын, 7.1\% буюу 554.319 мянган га талбайг уст болон хагас уст хэлбэршлийн, хамгийн бага $1.9 \%$ буюу 149.39 мянган га талбайг цөлийн тэжээлийн эдэлбэр тус тус эзлэж байгаа ба хээрийн бэлчээрийн нийт талбайгаас хуурай хээрийн бэлчээр 1163.120 мянган га, цөлийн хээр 786.190 мянган га талбайд тархаж байгаа нь аймгийн нийт тэжээлийн эдэлбэрийн 10 $14.8 \%$-тай тэнцэж байна.

Аймгийн дүнгээр зуны дээд ургацаар бодоход нийт 55975.15 мянган цн ургацын нөөцтэй бөгөөд үүнээс тэжээлийн өндөр ургацтай чанарын I бүлэгт голын сав, нуурын хөвөөний, нуга, нуга-намгийн, харьцангуй өндөр ургацтай чанарын III бүлэгт татмын нуга, нуга-намгийн тэжээлийн эдэлбэр орно.

Хадлан бэлчээрийн хэвшинж тус бүрийн даац, багтаамжийг тодорхойлсон дүнгээс үзэхэд Завхан аймгийн тэжээлийн эдэлбэр нутгийн жилийн нийт багтаамж 5660.9 мянган хонин толгойд хүрч байна. Тэжээлийн эдэлбэр нутгийн жилийн нийт багтаамжийн $69.5 \%$-ийг хээрийн бэлчээр эзлэж байна. Нийт бэлчээрийн багтаамжийг улирлаар тооцон гаргахад зуны улиралд 704.1 , зун-намрын улиралд 2633.9, өвөлхаврын улиралд 1949.73 мянган хонин толгой бэлчээрлүүлэх багтаамжтай юм.

нутгийн жилийн нийт багтаамж 5660.9 мянган хонин толгойд байна.

Завхан аймгийн бэлчээр зуны дээд ургацаар бодоход 55975.15 мянган цн ургацын нөөцтэй бөгөөд үүнээс тэжээлийн өндөр ургацтай чанарын I бүлэгт голын сав, нуурын хөвөөний, нуга, нуга-намгийн, харьцангуй өндөр ургацтай чанарын III бүлэгт татмын нуга, нуга-намгийн тэжээлийн эдэлбэр орно. 


\section{НОМ ЗҮЙ}

[1] Ганболд Э. Флора Северной Монголии (систематика, экология, география, история развития).-Труды Совместной Российско-Монгольской Комплексной Биологической экспедиции. T. LIII, 2010, 254 x.

[2] ГомболҮҮдэв П. Завхан аймгийн цаг уурын өөрчлөлт, чиг хандлага. Судалгааны ажлын тайлан 15 х. 2012.

[3] Методика рекомендации по оценке и картографированию современного состояния экосистем. Улаанбаатар, 1989, ст-71-72., 98-101.

[4] Нарантуяа Н., З.Цогт, И.Н. Сафранова. Завхан аймгийн экосистемийн судалгааны яви, үр дүн. Судалгааны ажльн тайлан. 16 x. 2015

[5] Николаев В.Н. Пустынное и полупустынное пастбище их оценка, использование и улучшение. // Проблемь освоения пустыни. 1981, №6, cm-41-49

[6] “Монгол орны хадлан, бэлчээр” ШУТ-ийн төслийн тайлан. 2004 


\title{
THE ISSUE OF HAY MAKING AND PASTURE LAND OF ZAVKHAN AIMAG
}

\author{
N.Narantuya ${ }^{l *}$
}

${ }^{l}$ Institute of General and experimental biology, MAS, Mongolia *corresponding author, e-mail: narntuya@gmail.com

\begin{abstract}
The article summarizes the results of pasture studies of recent years in Zavkhan aimag with the results of the previous years of Mongolian pasture land investigations. From the assessment of hay making pastures of the Zavkhan aimag for each area, yield and nutritional value, it has a total of 7850,366 thousand hectares of pasture land vegetation community has a yield in 6.5-7.7 c / ha, it has content of forage nutrient equal to $196.6-397 \mathrm{~kg} / \mathrm{ha}$ and the biological and ecological quality assessments of pasture land belonging to groups IY, Y, YI are widely distributed. Calculate by summer high yield, the total yield reserve is 55975.15 thousand centner and to high yielding quality group I includes the river valley, lake meadows and relatively high quality yields III group- flood meadows and some marshes.
\end{abstract}

Keywords: hay making, pasture land, pasture capacity, pasture type, biological and ecological quality assessment of pasture land; 